\title{
Metal Contamination in Cultivated Vegetables and Agricultural Soils Irrigated with Untreated Industrial Wastewater
}

\author{
U.S. Banerjee* and S. Gupta \\ Department of Environmental Science, The University of Burdwan, Golapbag 713104, West Bengal, India \\ Email:banerjeeenvsc@gmail.com
}

\begin{abstract}
The present study was conducted to determine the metal contamination in cultivated vegetables and agricultural soils irrigated with untreated industrial wastewater. Untreated industrial wastewaters pose a serious threat to ecosystem health and therefore, to check metal contamination in soil, eco-toxicological assessment of industrial effluents is necessary. The study deals with the characterization of effluent released from various industries and distribution of heavy metals in soil near to effluent discharge channel. The samples were analyzed for physico-chemical parameters using standard laboratory procedures and giving prime thrust to determine the heavy metal concentrations $(\mathrm{Pb}, \mathrm{Cd}, \mathrm{Mn}, \mathrm{Cu}$ and $\mathrm{Cr})$ of wastewater. The five heavy metals in the wastewater irrigated soil viz. $\mathrm{Pb}, \mathrm{Cd}, \mathrm{Mn}, \mathrm{Cu}$ and $\mathrm{Cr}$ were detected in most of the samples $(\mathrm{mg} / \mathrm{kg}$ ) ranged from 29.347-49.358, $0.169-2.265,75.786-95.228,2.852-15.532,26.969-49.245$ respectively. Enrichment of metals in wastewater irrigated soil sample ranged between $1.467-2.468(\mathrm{~Pb}), 0.563-7.550(\mathrm{Cd}), 0.089-0.112$ $(\mathrm{Mn}), 0.063-0.345(\mathrm{Cu})$, and $0.300-0.547(\mathrm{Cr})$. The soil of the agricultural land showed significant enrichment with $\mathrm{Pb}$ and $\mathrm{Cd}$ indicating inputs from industrial sources. From the above study, it has been found that the wastewaters at various locations are rich in essential micronutrients $(\mathrm{Mn}$ and $\mathrm{Cu})$ and have a good $\mathrm{pH}$ for agricultural use. The high values for $\mathrm{Cd}$ BCF may be explained by the fact that $\mathrm{Cd}$ is easily absorbed by plants. The depth wise study showed that metal concentrations were in higher magnitude at top-soil zone in comparison to sub-soil zone both in affected and control soils. The investigation showed pronounced metal contamination of agricultural soils irrigated with untreated industrial wastewater.
\end{abstract}

Keywords: Metal contamination, industrial wastewater, enrichment factor, geoaccumulation index, bioconcentration factor

\section{Introduction}

The application of industrial and city effluents to agricultural land has become popular in recent years as an alternative means of disposal. The unscientific disposal of toxic untreated or undertreated effluents has resulted in an accumulation of heavy metals in land and water bodies. The problem of crop irrigation in India is becoming very serious due to the water shortage that is being faced frequently. Metals are introduced into the environment in a number of ways. Heavy metals in agricultural soils may be from natural occurrence, as well as anthropogenic sources, such as mining, smelting, waste disposal, urban effluent, vehicle exhausts, sewage sludge, pesticides and fertilizers [1,2]. Heavy metals are discharged into the environment, through the wastewater generated from a variety of industries, such as galvanic, metallurgical, electronic, chloralkali etc. and create environmental problems. Excessive metal accumulation in contaminated soils can affect the soil microbial activity, soil fertility and overall soil quality, entry of toxic materials into the food chain and ultimately reductions in yield. Metal transport and availability in a heterogeneous system also depends on the interactions of the different geochemical species of metals present in the system [3]. Heavy metals do not degrade in the environment and so can remain in soil and water bodies for a long period of time. As metals are immobile in soil due to their high affinity for the soil matrix, they tend to accumulate there, mainly in the surface soil. The removal 
of toxic metals from wastewaters is of critical importance due to their high toxicity and tendency to accumulate in living organisms.

Soil/sediments act as a sensitive indicator for the monitoring of contaminants in an aquatic environment and as a result, are essential components in many nations and international monitoring programmes. Like other toxic pollutants, heavy metals have been of great concern due to their environmental persistence, toxicity. The $\mathrm{Cd}$ toxicity in man includes kidney damage [4] and pains in bones [5,6], also has mutagenic, carcinogenic and tetratogenic effects [7]. Chromium (Cr) and its compounds are very toxic and are primarily used in the manufacture of steel and other alloys, chrome plating and pigment production [8,9]. Copper is, however characterized by the point sources of contamination i.e. uncontrolled, active or untended waste dumps. Current research has focused on the influence of wastewater on heavy metal contamination and controlling factors in the surface environment and its implications for soils.

\section{$2 \quad$ Materials and Methods}

\subsection{Study Area}

The research work was conducted at Raniganj industrial complex in the Raniganj coalfield, situated in the western part of West Bengal, India. This region under the current status of a developing industrial zone consists of mainly large-scale industries such as steel plant, sponge iron and ferro alloy, along with petro-chemical and thermal power plants. These industries are thought to be prime contributors of water-borne heavy metals and responsible for the deterioration in water quality in the surrounding areas. The field study component of this research was performed in two different zones from which water and plant samples were collected. (1) Industrial area. The industrial sites were located within a $1-2 \mathrm{~km}$ radius of the core industrial area. This zone is enriched with a number of large-scale industries with a higher density of heavy vehicles. (2) Control area. To compare data from industrial site, an unpolluted site was selected and treated as the control. This zone is a residential area, located $8-10 \mathrm{~km}$ from industrial area. This zone has abundant green vegetation and a comparably lower traffic density.

\subsection{Sampling Strategy and Analytical Procedures}

Soil samples were collected both from wastewater irrigated and control site and kept immediately into polythene bags. Soil samples were air dried, crushed and sieved through 2-mm mesh and homogenized for further metal analysis. Plant samples were collected separately in polythene bags and taken to the laboratory as soon as possible. In laboratory, plant samples were thoroughly washed first with tap water followed by distilled water to get rid of soil/contaminants. For further metal analysis, plant samples were dried in room temperature, and then oven dried $\left(80{ }^{\circ} \mathrm{C}\right)$ for $24 \mathrm{~h}$. A tri-acid mixture $\left(70 \% \mathrm{HNO}_{3}\right.$, $65 \% \mathrm{HClO}_{4}$ and $\left.70 \% \mathrm{H}_{2} \mathrm{SO}_{4} ; 5: 1: 1\right)$ was used to digest dried soil and plant samples [10]. Digested samples were filtered (Whatman 42 filter paper), diluted to $50 \mathrm{ml}$ and analysed for $\mathrm{Pb}, \mathrm{Cd}, \mathrm{Mn}, \mathrm{Cu}$ and $\mathrm{Cr}$ in an atomic absorption spectrophotometer (GBC Avanta).

\subsection{Index for Assessing Metal Pollution in Soil}

The concentrations of metals in agricultural soil can be sensitive indicators of contaminants. To assess the degree of contamination of heavy metals in the soil samples, the enrichment factor (EF), and geoaccumulation index (Igeo) is applied for the study.

\subsubsection{Enrichment Factor (EF)}

In order to assess the enrichment of metals in soils and to quantify the industrial input, the geochemical normalization approach is applied, and it is calculated according to the following equation.

$$
\mathrm{EF}=(\mathrm{M} / \mathrm{X}) \text { sample/ }(\mathrm{M} / \mathrm{X}) \text { background }
$$

where $M$ is the measured concentration of the element in the sediment, $X$ is the selected normalizer (reference metal) and $(M / X)$ sample and $(M / X)$ background are the ratios of target metal and the normalizer in the interest and background sediments, respectively. Enrichment factor (EF) is a method to estimate the anthropogenic impact on soil/sediments is to calculate a normalized enrichment factor 
(EF) for metal concentrations above uncontaminated background levels [11]. Inert elements $\mathrm{Al}$ and $\mathrm{Fe}$ are less anthropogenic contamination in soil/aquatic sediment and were used as the normalizer most frequently [12]. In this study iron is used as normalizer. A five-category ranking system is used to express the degree of anthropogenic contamination. EF $<2$ is deficiency to minimal contamination, EF $=2-5$ moderate contamination, $\mathrm{EF}=5-20$ significant contamination, $\mathrm{EF}=20-40$ very high contamination, and EF > 40 extremely high contamination [13].

\subsubsection{Geoaccumulation Index (Igeo)}

The Igeo method was used to calculate the metal contamination levels in soil. Geoaccumulation index (Igeo) estimates the enrichment of metal concentrations in soil above background or baseline concentrations and is calculated according to the equation below:

$$
\mathrm{Igeo}=\log 2 \mathrm{Cn} / 1.5 \mathrm{Bn}
$$

where $\mathrm{Cn}$ is the concentration of the element in the enriched samples, and the $\mathrm{Bn}$ is the background value of the element. Following descriptive classification for geoaccumulation is given for the index of accumulation [14]: $<0=$ uncontaminated, $0-1=$ uncontaminated to moderately contaminated, $1-2=$ moderately contaminated, $2-3=$ moderately to heavily contaminated, $3-4=$ heavily contaminated, 4-5 $=$ heavily to extremely contaminated, $>5$ extremely contaminated.

\subsection{Bioconcentration Factor (BCF)}

For estimating metal concentrations in vegetables, the important parameter is the Bioconcentration Factor $(\mathrm{BCF})$. It is the ratio of metal concentration in the vegetable and metal concentration in soil, i.e.

$$
\text { Bioconcentration Factor }(\mathrm{BCF})=\frac{\text { Metal concentration in vegetable }(\mathrm{mg} / \mathrm{kg} \text { of vegetab) }}{\text { Metal concentration in soil }(\mathrm{mg} / \mathrm{kg} \text { of soil })}
$$

\subsection{Quality Control Assurances}

As a quality control measure, care was taken to collect fresh, uninfected, healthy plant samples from both the control and polluted sites for investigation. E-mark standard solutions (AR grade, Germany) were used for atomic absorption spectrophotometer calibration to detect heavy metal concentrations in digested samples. To maintain accuracy, control standard solutions (blanks) were used at the beginning and after every five samples. Each analytical method was performed in triplicate to ensure the accuracy and reliability of the obtained results and only mean values with standard deviation (SD) were considered.

\section{$3 \quad$ Results and Discussion}

\subsection{Characterizations of the Untreated Wastewater}

Characterizations of the untreated wastewater are presented in Table 1 . The $\mathrm{pH}$ level of a water system determines its usefulness for a variety of purposes. The very high fluctuation of $\mathrm{pH}$ has been reported to be toxic to aquatic life and alter the solubility of other chemical pollutants as well as some essential elements in water systems [15], thereby causing adverse effects on the ecosystem and those who depend on it. The $\mathrm{pH}$ value of the analyzed samples varied from 7.15 to 8.00 with a mean value of 7.58 \pm 0.29 . Specific conductance is related to the total concentration of the ionized substances in the water at a particular temperature [16]. Electrical conductivity, an indicator of the concentration of total dissolved ions is a valuable tool in assessing water quality [17]. Electrical conductivity is an important parameter to assess the water quality for irrigation use as the high salt content in irrigation water causes an increase in soil solution osmotic pressure. The high level of salts besides affecting the growth of the plants directly, also affects the soil structure, permeability and aeration which indirectly affect the plant growth. The value of electrical conductivity ranged from 400 to $650 \mu \mathrm{S} / \mathrm{cm}$ with a mean value of $522.2 \pm 76.35 \mathrm{\mu S} / \mathrm{cm}$ for measured samples. Total dissolved solid (TDS) as a measure of salinity is an important agricultural water quality parameter with respect to soil salinity. The total dissolved solids (TDS), which is the sum of the dissolved ionic concentrations, ranged from $262.44 \mathrm{mg} / 1$ to $431.26 \mathrm{mg} / \mathrm{l}$ with a mean value of $339.99 \pm 50.69 \mathrm{mg} / \mathrm{l}$. 
Table 1. pH, EC, TDS and metal concentrations of the untreated wastewater

\begin{tabular}{lrrrrllll}
\hline & $\mathrm{pH}$ & $\mathrm{EC}$ & $\mathrm{TDS}$ & $\mathrm{Pb}$ & $\mathrm{Cd}$ & $\mathrm{Mn}$ & $\mathrm{Cu}$ & $\mathrm{Cr}$ \\
\hline $\mathrm{S} 1$ & 7.53 & 630 & 416.75 & 43.685 & 0.365 & 0.687 & 12.754 & 3.357 \\
$\mathrm{~S} 2$ & 7.35 & 650 & 431.26 & 44.525 & 1.268 & 0.725 & 17.523 & 3.526 \\
$\mathrm{~S} 3$ & 7.15 & 560 & 368.54 & 39.964 & 0.325 & 0.653 & 15.289 & 3.427 \\
$\mathrm{~S} 4$ & 7.83 & 530 & 338.28 & 36.786 & 0.315 & 0.752 & 16.875 & 3.475 \\
$\mathrm{~S} 5$ & 8.00 & 470 & 298.75 & 35.421 & 0.296 & 0.526 & 8.539 & 2.634 \\
$\mathrm{~S} 6$ & 7.75 & 510 & 329.43 & 36.972 & 0.314 & 2.786 & 16.754 & 1.964 \\
$\mathrm{~S} 7$ & 7.65 & 480 & 309.79 & 42.415 & 0.309 & 0.457 & 12.759 & 2.337 \\
$\mathrm{~S} 8$ & 8.00 & 550 & 362.53 & 39.541 & 1.254 & 0.634 & 14.969 & 0.985 \\
$\mathrm{~S} 9$ & 7.86 & 400 & 262.44 & 40.571 & 0.568 & 2.324 & 12.645 & 2.914 \\
$\mathrm{~S} 10$ & 7.25 & 600 & 384.64 & 43.654 & 1.635 & 0.329 & 16.298 & 3.195 \\
$\mathrm{~S} 11$ & 8.00 & 510 & 335.69 & 40.241 & 0.892 & 2.241 & 16.997 & 3.376 \\
$\mathrm{~S} 12$ & 7.54 & 460 & 305.79 & 39.964 & 0.639 & 0.452 & 12.927 & 0.989 \\
$\mathrm{~S} 13$ & 7.29 & 530 & 338.64 & 37.254 & 1.589 & 0.527 & 10.650 & 0.996 \\
$\mathrm{~S} 14$ & 7.74 & 410 & 272.66 & 41.425 & 0.875 & 0.415 & 17.632 & 2.587 \\
$\mathrm{~S} 15$ & 7.15 & 470 & 299.89 & 29.324 & 0.786 & 0.429 & 16.967 & 3.652 \\
$\mathrm{~S} 16$ & 7.25 & 550 & 363.35 & 39.524 & 0.526 & 0.245 & 18.215 & 3.991 \\
$\mathrm{~S} 17$ & 7.65 & 650 & 418.89 & 38.248 & 1.345 & 0.474 & 14.415 & 2.118 \\
$\mathrm{~S} 18$ & 7.49 & 440 & 282.56 & 34.634 & 0.428 & 1.247 & 12.897 & 3.973 \\
Min & 7.15 & 400 & 262.44 & 29.324 & 0.296 & 0.245 & 8.539 & 0.985 \\
Max & 8.00 & 650 & 431.26 & 44.525 & 1.635 & 2.786 & 18.215 & 3.991 \\
Ave & 7.58 & 522.2 & 339.99 & 39.119 & 0.763 & 0.884 & 14.728 & 2.750 \\
SD & 0.29 & 76.35 & 50.69 & 3.726 & 0.467 & 0.759 & 2.699 & 0.998 \\
\hline
\end{tabular}

EC is expressed as $\mu \mathrm{S} / \mathrm{cm}$ and TDS as $\mathrm{mg} / \mathrm{L}$ other parameters (except $\mathrm{pH}$ ) are in $\mu \mathrm{g} / \mathrm{L}$

Relationships of the metals with each other and with the $\mathrm{pH}$, electrical conductivity and total dissolved solid in water when studied through correlation analysis indicated some statistically significant relationships, which are depicted in Table 2. Amongst the studied metals, $\mathrm{Cr}$ and $\mathrm{Pb}$ showed a strong positive correlation indicating that they may be entering through common source and mutually favoring their adsorption on the soils. The significant positive correlations within these metals reveal their common source viz., industrial contamination, and sinks in soils of the study area. Lead is released from smelting, motor-vehicle exhausts fumes and from corrosion of lead pipe work and its solubility is controlled principally by $\mathrm{PbCO}_{3}$ and low-pH waters can have higher $\mathrm{Pb}$ concentrations. $\mathrm{Cd}$ and $\mathrm{Pb}$ concentration in the analysed wastewater samples ranged from 0.296 to $1.635 \mathrm{\mu g} / \mathrm{l}$ and 29.324 to 44.525 $\mu \mathrm{g} / \mathrm{l}$ respectively. The manganese, copper and chromium concentration in the analysed wastewater samples ranged from 0.245 to $2.786 \mu \mathrm{g} / \mathrm{l}, 8.539$ to $18.215 \mu \mathrm{g} / \mathrm{l}$ and 0.985 to $3.991 \mathrm{\mu g} / \mathrm{l}$ respectively. Long-term use of contaminated wastewater can enrich heavy metal to phototoxic levels and result in reduced plant growth and/or enhanced metal concentration in plants which has an ultimate detrimental effect on the livestock.

\subsection{Characterizations of the Wastewater Irrigated Soil}

Depth wise distributions of heavy metals in wastewater irrigated soil and control soil $(\mathrm{mg} / \mathrm{kg})$ in studied area are presented in Table 3. The top-soil layer in wastewater irrigated area (depth $0-20 \mathrm{~cm})$ contains $\mathrm{Pb}$ concentration higher $(49.358 \mathrm{mg} / \mathrm{kg})$ than sub-soil layer 5 (depth 100-150 cm) $(29.347 \mathrm{mg} / \mathrm{kg}) . \mathrm{In}$ wastewater irrigated soil the $\mathrm{Cd}$ and $\mathrm{Mn}$ concentration at top-soil layer was $2.265 \mathrm{mg} / \mathrm{kg}$ and 95.228 $\mathrm{mg} / \mathrm{kg}$ respectively and at the sub-soil layer 5 the concentration was $0.169 \mathrm{mg} / \mathrm{kg}$ and $75.786 \mathrm{mg} / \mathrm{kg}$ respectively. In wastewater irrigated soil the $\mathrm{Cu}$ and $\mathrm{Cr}$ concentration was $15.532 \mathrm{mg} / \mathrm{kg}$ and 49.245 $\mathrm{mg} / \mathrm{kg}$ respectively in top-soil layer and $2.852 \mathrm{mg} / \mathrm{kg}$ and $26.969 \mathrm{mg} / \mathrm{kg}$ respectively in sub-soil layer 5 soils. The five heavy metals in the control soil viz. $\mathrm{Pb}, \mathrm{Cd}, \mathrm{Mn}, \mathrm{Cu}$ and $\mathrm{Cr}$ that were detected in most of the samples $(\mathrm{mg} / \mathrm{kg})$ ranged from 16.469-37.272, 0.027-0.863, 25.896-54.145, 1.241-5.786, 9.77328.125 respectively. These studied heavy metals decreased with depth in both affected and control soils. 
The increment of the studied heavy metals in the top-soil layer $(0-20 \mathrm{~cm})$ is due to the impact of untreated industrial wastewater. The results of the study show the impact of anthropogenic agents on abundances of heavy metals in soils of the study area and it is extremely contaminated due to many years of random dumping of hazardous waste and free discharge of effluents by a number of industries. Though the wastewater contains low levels of the heavy metals ( $\mathrm{Pb}, \mathrm{Cd}, \mathrm{Mn}, \mathrm{Cu}$ and $\mathrm{Cr}$ ), the soil samples show higher values due to accumulation.

Table 2. Correlation matrix of physicochemical variables in wastewater

\begin{tabular}{lllllllll}
\hline & $\mathrm{pH}$ & $\mathrm{EC}$ & $\mathrm{TDS}$ & $\mathrm{Pb}$ & $\mathrm{Cd}$ & $\mathrm{Mn}$ & $\mathrm{Cu}$ & $\mathrm{Cr}$ \\
\hline $\mathrm{pH}$ & 1 & & & & & & & \\
$\mathrm{EC}$ & -0.660 & 1 & & & & & & \\
$\mathrm{TDS}$ & -0.689 & 0.999 & 1 & & & & & \\
$\mathrm{~Pb}$ & -0.731 & 0.798 & 0.800 & 1 & & & & \\
$\mathrm{Cd}$ & -0.420 & 0.688 & 0.686 & 0.438 & 1 & & & \\
$\mathrm{Mn}$ & 0.171 & -0.138 & -0.137 & 0.060 & -0.120 & 1 & & \\
$\mathrm{Cu}$ & -0.458 & 0.463 & 0.454 & 0.786 & 0.443 & 0.416 & 1 & \\
$\mathrm{Cr}$ & -0.672 & 0.624 & 0.623 & 0.904 & 0.450 & -0.197 & 0.757 & 1 \\
\hline \multicolumn{7}{c}{ * Values in bold are significant $\mathrm{p}<.01$} \\
\end{tabular}

Table 3. Depth wise distribution of heavy metals $(\mathrm{mg} / \mathrm{kg})$ in studied soils

\begin{tabular}{|c|c|c|c|c|c|c|c|}
\hline Soil & Layer & Depth $(\mathrm{cm})$ & $\mathrm{Pb}$ & $\mathrm{Cd}$ & Mn & $\mathrm{Cu}$ & $\mathrm{Cr}$ \\
\hline \multirow{6}{*}{ 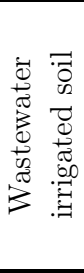 } & Top-soil layer & $0-20$ & 49.358 & 2.265 & 95.228 & 15.532 & 49.245 \\
\hline & Sub-soil layer 1 & $20-40$ & 45.258 & 1.349 & 87.235 & 10.514 & 42.232 \\
\hline & Sub-soil layer 2 & $40-60$ & 42.326 & 0.939 & 84.639 & 8.232 & 36.531 \\
\hline & Sub-soil layer 3 & $60-80$ & 39.425 & 0.786 & 82.321 & 6.242 & 30.342 \\
\hline & Sub-soil layer 4 & $80-100$ & 37.329 & 0.526 & 72.532 & 3.755 & 28.327 \\
\hline & Sub-soil layer 5 & $100-150$ & 29.347 & 0.169 & 75.786 & 2.852 & 26.969 \\
\hline \multirow{5}{*}{$\begin{array}{l}\overline{0} \\
0 \\
0 \\
0 \\
0 \\
0 \\
0 \\
0 \\
0\end{array}$} & Top-soil layer & $0-20$ & 37.272 & 0.863 & 54.145 & 5.786 & 28.125 \\
\hline & Sub-soil layer 1 & $20-40$ & 34.122 & 0.543 & 44.528 & 4.547 & 24.443 \\
\hline & Sub-soil layer 2 & $40-60$ & 29.425 & 0.142 & 40.471 & 4.247 & 17.214 \\
\hline & Sub-soil layer 3 & $60-80$ & 19.758 & 0.063 & 32.426 & 2.127 & 12.325 \\
\hline & Sub-soil layer 4 & $80-100$ & 16.469 & 0.027 & 25.896 & 1.241 & 9.773 \\
\hline
\end{tabular}

\subsection{Soil Quality Assessment of the Control and Wastewater Irrigated Site}

\subsubsection{Enrichment Factor (EF)}

The top-soil layer in wastewater irrigated area (depth 0-20 cm) contains Pb EF higher (2.468) than sub-soil layer 5 (depth 100-150 cm) (1.467). In wastewater irrigated soil the EF of Mn at top-soil layer was 0.112 and at the sub-soil layer 5 the $\mathrm{EF}$ was 0.089. In wastewater irrigated soil the $\mathrm{Cu}$ and $\mathrm{Cr} \mathrm{EF}$ was 0.345 and 0.547 respectively in top-soil layer and 0.083 and 0.315 respectively in sub-soil layer 5 soils. The wastewater irrigated soils thus recorded minimal enrichment to significant enrichment of $\mathrm{Cd}$ contamination as evident from the enrichment factor found in the present study, ranging from 0.563 to 7.550 (Table 4). This indicates substantial anthropogenic flux of Cd into the study area. The five heavy metals in the control soil viz. $\mathrm{Pb}, \mathrm{Cd}, \mathrm{Mn}, \mathrm{Cu}$ and $\mathrm{Cr}$ that were detected in most of the samples $(\mathrm{mg} / \mathrm{kg})$ ranged from $0.823-1.864,0.090-2.877,0.030-0.064,0.028-0.129,0.109-0.314$ respectively. The high value of EF indicates substantial anthropogenic flux of heavy metals into the study area. 
Table 4: Depth wise Enrichment factor (EF) values of the soil in the studied area

\begin{tabular}{|c|c|c|c|c|c|c|c|}
\hline Soil & Layer & Depth $(\mathrm{cm})$ & $\mathrm{Pb}$ & $\mathrm{Cd}$ & Mn & $\mathrm{Cu}$ & $\mathrm{Cr}$ \\
\hline \multirow{6}{*}{ 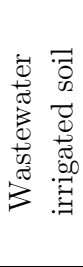 } & Top-soil layer & $0-20$ & 2.46 & 7.550 & .112 & 0.345 & 0.547 \\
\hline & Sub-soil layer 1 & $20-40$ & 2.263 & 4.497 & 0.103 & 0.234 & 0.469 \\
\hline & Sub-soil layer 2 & $40-60$ & 2.116 & 3.130 & 0.100 & 0.183 & 0.406 \\
\hline & Sub-soil layer 3 & $80-80$ & 1.971 & 2.620 & 0.097 & 0.139 & 0.337 \\
\hline & Sub-soil & $0-100$ & 1.866 & 1.753 & 0.085 & 0.083 & 0.315 \\
\hline & Sub-soil la & $100-150$ & 1.467 & 0.563 & 0.089 & 0.063 & 0.300 \\
\hline \multirow{5}{*}{$\begin{array}{l}\bar{\nabla} \\
0 \\
0 \\
0 \\
0 \\
0 \\
0 \\
0\end{array}$} & Top-soil layer & $0-20$ & 1.864 & 2.877 & 0.064 & 0.129 & 0.314 \\
\hline & Sub-soil layer 1 & $20-40$ & 1.706 & 1.810 & 0.052 & 0.101 & 0.272 \\
\hline & Sub-soil layer 2 & $40-60$ & 1.471 & 0.473 & 0.048 & 0.094 & 0.191 \\
\hline & Sub-soil layer 3 & $60-80$ & 0.988 & 0.210 & 0.038 & 0.047 & 0.137 \\
\hline & Sub-soil layer 4 & $80-100$ & 0.823 & 0.090 & 0.030 & 0.028 & 0.109 \\
\hline
\end{tabular}

\subsubsection{Index of Geoaccumulation (Igeo)}

On the basis of geoaccumulation index (Igeo), the study revealed that manganese, copper and chromium was practically uncontaminated in the control and wastewater irrigated site. In wastewater irrigated soil the Igeo of $\mathrm{Pb}$ ranged from minimum of -0.032 to maximum of 0.718 (Table 5) which indicates uncontaminated to moderately contaminated status. Igeo of $\mathrm{Cd}$ in wastewater irrigates soil ranged from minimum of -1.414 to 2.332 and this indicates uncontaminated to heavily contaminated soil. The metal enrichment factor and geoaccumulation index of $\mathrm{Cd}$, and $\mathrm{Pb}$ suggest in general concentrations above background levels in the study area, while concentrations of other metals $(\mathrm{Cu}, \mathrm{Mn}$ and $\mathrm{Cr}$ ) are generally within background concentration ranges. It can be noticed that the soils in the study areas have considerably higher concentrations for the $\mathrm{Pb}$ and $\mathrm{Cd}$ metals. This characterizes the agricultural soil as polluted due to proximity to industrial sites and sewage disposal points.

Table 5. Depth wise Geoaccumulation Index (Igeo) values of the soil in the studied area

\begin{tabular}{|c|c|c|c|c|c|c|c|}
\hline Soil & Layer & Depth $(\mathrm{cm})$ & $\mathrm{Pb}$ & $\mathrm{Cd}$ & $\mathrm{Mn}$ & $\mathrm{Cu}$ & $\mathrm{Cr}$ \\
\hline \multirow{6}{*}{ 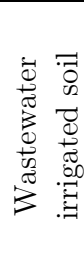 } & Top-soil layer & $0-20$ & 0.718 & 2.332 & -3.743 & -2.120 & -1.455 \\
\hline & Sub-soil layer 1 & $20-40$ & 0.593 & 1.584 & -3.869 & -2.683 & -1.677 \\
\hline & Sub-soil layer 2 & $40-60$ & 0.497 & 1.061 & -3.913 & -3.036 & -1.886 \\
\hline & Sub-soil layer 3 & $60-80$ & 0.394 & 0.805 & -3.953 & -3.435 & -2.154 \\
\hline & Sub-soil layer 4 & $80-100$ & 0.315 & 0.225 & -4.136 & -4.168 & -2.253 \\
\hline & Sub-soil layer 5 & $100-150$ & -0.032 & -1.414 & -4.072 & -4.565 & -2.324 \\
\hline \multirow{5}{*}{$\begin{array}{l}\overline{0} \\
0 \\
\overline{0} \\
0 \\
0 \\
0 \\
0 \\
0\end{array}$} & Top-soil layer & $0-20$ & 0.313 & 0.939 & -4.558 & -3.544 & -2.263 \\
\hline & Sub-soil layer 1 & $20-40$ & 0.186 & 0.271 & -4.840 & -3.892 & -2.465 \\
\hline & Sub-soil layer 2 & $40-60$ & -0.028 & -1.664 & -4.977 & -3.990 & -2.971 \\
\hline & Sub-soil layer 3 & $60-80$ & -0.603 & -2.837 & -5.297 & -4.988 & -3.453 \\
\hline & Sub-soil layer 4 & $80-100$ & -0.865 & -4.059 & -5.622 & -5.765 & -3.788 \\
\hline
\end{tabular}

\subsubsection{Heavy Metal Accumulation in Plant}

The results of the heavy metal content in plant material along with bio-concentration factor (BCF) values of the wastewater-irrigated and control sites are presented in Table 6. Generally biomass uptakes trace metals naturally available to them through soil and store them in their tissues. According to [18] Sharma et al. 2007 absorption and accumulation of heavy metals in plant tissue depend upon several factors, which include temperature, moisture, $\mathrm{pH}$, and nutrient availability. All the samples were analyzed to determine the heavy metal content of plants. The $\mathrm{Cd}$ concentration in cauliflower (8.958 $\mu \mathrm{g} / \mathrm{g}$ ) and its BCF value (3.955) was found to be highest in wastewater irrigated area. At the control site the $\mathrm{Cd}$ concentration of cauliflower was 1.745 and the $\mathrm{BCF}$ value was 2.022. The highest $\mathrm{Pb}$ concentration $(35.842 \mathrm{\mu g} / \mathrm{g}$ ) and its BCF value (0.726) was found in spinach at the wastewater irrigated 
area. In wastewater irrigated area the Mn concentration was highest in the root of Raphanus sativus $(109.87 \mathrm{\mu g} / \mathrm{g})$ and the fruit of Solanum melongena $(83.256 \mathrm{\mu g} / \mathrm{g})$ with BCF values 1.154 and 0.874 respectively. $\mathrm{Cu}$ concentration in Solanum melongena is $29.786 \mathrm{\mu g} / \mathrm{g}$ with the BCF value 1.918. The highest $\mathrm{Cr}$ concentration $(78.328 \mathrm{\mu g} / \mathrm{g})$ and its $\mathrm{BCF}$ value (1.591) was found in spinach at the wastewater irrigated area. At the control site the Cr concentration was $48.246 \mathrm{\mu g} / \mathrm{g}$ and the BCF value was 1.751. Higher concentrations of metals in soil where the vegetable is cultivated by the wastewater may be the reason for higher BCF. From the study it was observed that, other than $\mathrm{Pb}$, the $\mathrm{Cd}, \mathrm{Mn}$, $\mathrm{Cu}$ and $\mathrm{Cr}$ had a remarkable BCF values greater than 1 in wastewater irrigated area. In all cases, the $\mathrm{BCF}$ values for $\mathrm{Pb}$ are less than 1 indicating the low mobilities of this metal to plants. It is also observed that in most of the cases the $\mathrm{BCF}$ of $\mathrm{Cd}$ is greater than 1 indicating its high mobility from soil to plants. The high values for $\mathrm{Cd}$ BCF may be explained by the fact that $\mathrm{Cd}$ is easily absorbed by plants.

Table 6. Metal concentrations ( $\mathrm{mg} \mathrm{kg}-1 \mathrm{DM})$ in wastewater irrigated crop plants

\begin{tabular}{|c|c|c|c|c|c|c|}
\hline & & $\mathrm{Pb}$ & $\mathrm{Cd}$ & $\mathrm{Mn}$ & $\mathrm{Cu}$ & $\mathrm{Cr}$ \\
\hline \multirow[t]{4}{*}{ Spinach (Leaf) } & \multirow[t]{2}{*}{ Wastewater } & 35.842 & 7.786 & 90.528 & 25.824 & 78.328 \\
\hline & & $(0.726)$ & $(3.438)$ & $(0.951)$ & $(1.663)$ & $(1.591)$ \\
\hline & \multirow[t]{2}{*}{ Control } & 6.357 & 1.546 & 42.024 & 5.326 & 48.246 \\
\hline & & $(0.171)$ & $(1.791)$ & $(0.776)$ & $(0.920)$ & $(1.751)$ \\
\hline \multirow[t]{4}{*}{ Cauliflower (Inflorescence) } & \multirow[t]{2}{*}{ Wastewater } & 25.265 & 8.958 & 87.245 & 10.472 & 72.635 \\
\hline & & $(0.512)$ & $(3.955)$ & $(0.916)$ & $(0.674)$ & $(1.475)$ \\
\hline & \multirow[t]{2}{*}{ Control } & 4.187 & 1.745 & 34.258 & 2.965 & 42.379 \\
\hline & & $(0.112)$ & $(2.022)$ & $(0.633)$ & $(0.512)$ & $(1.507)$ \\
\hline \multirow[t]{4}{*}{ Raphanus sativus (root) } & \multirow[t]{2}{*}{ Wastewater } & 20.324 & 5.524 & 109.87 & 18.412 & 62.985 \\
\hline & & $(0.412)$ & $(2.439)$ & $(1.154)$ & $(1.185)$ & $(1.279)$ \\
\hline & \multirow[t]{2}{*}{ Control } & 3.425 & 0.896 & 65.324 & 4.269 & 36.398 \\
\hline & & $(0.092)$ & $(1.038)$ & $(0.686)$ & $(0.738)$ & $(1.294)$ \\
\hline \multirow[t]{4}{*}{ Raphanus sativus (shoot) } & \multirow[t]{2}{*}{ Wastewater } & 12.968 & 4.527 & 98.527 & 16.987 & 50.951 \\
\hline & & $(0.263)$ & $(1.999)$ & $(1.035)$ & $(1.094)$ & $(1.035)$ \\
\hline & \multirow[t]{2}{*}{ Control } & 3.587 & 0.786 & 30.247 & 3.951 & 24.832 \\
\hline & & $(0.096)$ & $(0.911)$ & $(0.559)$ & $(0.683)$ & $(0.883)$ \\
\hline \multirow[t]{4}{*}{ Solanum melongena (fruit) } & \multirow[t]{2}{*}{ Wastewater } & 32.632 & 6.635 & 83.256 & 29.786 & 48.934 \\
\hline & & $(0.661)$ & $(2.929)$ & $(0.874)$ & $(1.918)$ & $(0.994)$ \\
\hline & \multirow[t]{2}{*}{ Control } & 5.268 & 0.934 & 29.657 & 7.657 & 19.974 \\
\hline & & $(0.141)$ & $(1.082)$ & $(0.548)$ & $(1.323)$ & $(0.710)$ \\
\hline
\end{tabular}

Values in parenthesis are BCF (bio-concentration factor)

\section{Conclusion}

The investigation shows that effluent is the main source of pollution of agricultural land and thereby irrigation with contaminated wastewater leads to increase in metal concentration in soil. From the above study, it has been found that the wastewaters at various locations are rich in essential micronutrients $(\mathrm{Mn}$ and $\mathrm{Cu}$ ) and have a good $\mathrm{pH}$ for agricultural use. Results reveal that variations in element concentrations in soils of the study area have both natural and anthropogenic influences among which anthropogenic influence is more significant. Metal concentrations were in higher magnitude at surface soil zone in comparison to bottom layer both in wastewater irrigated and control soils. This is important to note that the effluent from the wastewater channel under study is a threat to agricultural land. The high values for $\mathrm{Cd}$ BCF may be explained by the fact that $\mathrm{Cd}$ is easily absorbed by plants. There were variations in the metal properties of soils affected by wastewater when compared with unaffected (control) soils. So, proper care should be taken to treat the agricultural soils before use for irrigation purposes. Therefore, the wastewater should be subjected to suitable chemical treatments especially for keeping the metals within the safe levels. 
Acknowledgements. The authors wish to thank Prof. J.K. Datta, Prof A.R. Ghosh, Dr N.K. Mondal, Dept of Environmental Science, The University of Burdwan for their valuable suggestions and cooperation throughout this research work. The authors also acknowledge the help and encouragement rendered by Mr. Jagadish Mondal, Asst. teacher, Mohanpur High School, Burdwan, West Bengal, India.

\section{References}

1. B. J. Alloway, Heavy metals in soils (2nd Ed.). London: Blackie and Son, Chap. 3, pp. 368, 1995.

2. A. G. Kachenko and B. Singh, "Heavy metals contamination in vegetables grown in urban and metal smelter contaminated sites in Australia," Water Air \& Soil Pollution, vol. 169, pp. 101-123, 2006.

3. Z. L. He, M. K. Zhang, D. V. Calvert, P. J. Stoffella, X. E. Yang and S. Yu, "Transport of heavy metals in surface runoff from vegetable and citrus fields," Soil Science Society of America Journal, vol. 68, pp. 1662-1669, 2004.

4. F. R. M. Herber, M. A. Verschoor and A. A. E. Wibowo, "A review of kinetics and kidney effects of cadmium. Recent epidemiological studies," Environmental Toxins, Berlin: Springer, vol. 2, 1988, pp. 115-133.

5. K.Tsuchiya, Cadmium studies in Japan - A review. Tokyo: Kodansha, 1978.

6. A. Bernard, "Cadmium \& its adverse effects on human health," Indian J Med Res, vol. 128, October, pp 557-564, 2008.

7. L. Frieberg, C. G. Elinder, T. Kjellstroem, and C. F. Nordberg, Cadmium and Health: A toxicological and epidemiological appraisal. Volume II, effects and response. Boca Raton, Florida: CRC, 1986.

8. P. K. Govil, G. L. N. Reddy and A. K. Krishna, "Soil Contamination due to heavy metals in Patancheru industrial development area," Environmental Geology, vol. 41, pp. 461-469, 2001.

9. A. K. Krishna and P. K. Govil, "Heavy metal distribution and contamination in soils of Thane-Belapur industrial development area, Mumbai, Western India," Environmental Geology, vol. 47, no.8, pp. 1054-1061, 2005.

10.S.E. Allen, H.M. Grimshaw and A.P. Rowland, Chemical analysis, in Methods in Plant Ecology, P.D. Moore and S.B. Chapman, eds., Blackwell Scientific, Oxford, pp. 285-344, 1986.

11.W. W. Dickinson, G. B. Dunbar, and H. McLeod, "Heavy metal history from cores in Wellington Harbour, New Zealand," Environmental Geology, vol. 27, pp. 59-69, 1996.

12.T. Liaghati, M. Preda and M. Cox, "Heavy metal distribution and controlling factors within coastal plain sediments, Bells Creek Catchment, southeast Queensland, Australia," Environment International, vol. 29, pp.935-948, 2003.

13.R. A. Sutherland, "Bed sediment-associated trace metals in an urban stream, Oahu, Hawaii," Environmental Geology, vol. 39, pp.611-627, 2000.

14.G. Muller, "Index of geoaccumulation in sediments of the Rhine River," Geojournal, vol. 2, pp.109-118, 1969.

15.DWAF, South African water quality guidelines (Vol. 7), aquatic ecosystems (1st ed.). Pretoria: Department of Water Affairs and Forestry, 1996.

16.APHA, Standard methods for the examination of water and wastewater. 17th Edn. Washington DC, USA, 1985.

17.M. Shariatpatanahi, and A. C. Anderson, "Survey of chemical constituents of Tehran's groundwater," Journal of Environmental Geochemistry and Health, vol. 9, pp. 55-601, 1987.

18.R. K. Sharma, M. Agrawal, and F. Marshal, "Heavy metal contamination of soil and vegetables in suburban areas of Varanasi, India," Ecotoxicology and Environmental Safety, vol. 66, no. 2, pp. 258-266, 2007. 